\title{
HIDRODINAMIKA DAN KUALITAS PERAIRAN \\ UNTUK KESESUAIAN PEMBANGUNAN KERAMBA JARING APUNG (KJA) OFFSHORE DI PERAIRAN KENEUKAI, NANGROE ACEH DARUSSALAM
}

\author{
MARINE HYDRODYNAMICS AND WATER QUALITY \\ REQUIREMENTS FOR OFFSHORE FLOATING MARINE FISH CAGE \\ AQUACULTURE SITE SELECTION IN KENEUKAI OFFSHORE \\ COASTAL WATERS, NANGROE ACEH DARUSALAM
}

\author{
Koko Ondara, Guntur Adhi Rahmawan, Ulung Jantama Wisha dan Nia Naelul Hasanah Ridwan \\ Loka Riset Sumber Daya dan Kerentanan Pesisir \\ Pusat Riset Kelautan, Kementerian Kelautan Dan Perikanan \\ Jl. Raya Padang - Painan KM. 16, Bungus, Padang, Sumatera Barat 25245 \\ e-mail : koko_ondara@alumni.itb.ac.id
}

Diterima tanggal: 14 Desember 2016 ; diterima seletah perbaikan: 7 Maret 2017 ; Disetujui tanggal: 6 April 2017

\begin{abstract}
ABSTRAK
Perairan Keneukai merupakan salah satu penghasil sumber daya perikanan di Pulau Weh, Nanggroe Aceh Darussalam. Jumlah spesies ikan di perairan tersebut mengalami penurunan dari tahun 2008 hingga 2010. Penelitian yang dilakukan oleh Loka Riset Sumber Daya dan Kerentanan Pesisir (LRSDKP) pada tahun 2017 mempunyai salah satu tujuan untuk menentukan lokasi yang tepat untuk usaha budi daya perairan Keramba Jaring Apung (KJA) lepas pantai di Perairan Keneukai. Analisis yang dilakukan dalam penelitian ini adalah analisis arus, pasang surut, batimetri, serta kualitas perairan. Kecepatan arus di permukaan berkisar antara 0-0,9 m/s. Sementara itu, kecepatan arus dekat dasar berkisar antara 0-0,74 m/s. Profil vertikal arus menunjukkan mekanisme Spiral Ekman yang berpengaruh terhadap distribusi material-mateial organik secara vertikal dan didominasi oleh arus pasang surut. Topografi Perairan Keneukai termasuk landai dengan kedalaman berkisar 0-72 meter dan terdapat perubahan kedalaman yang signifikan di sejumlah area. Hasil analisis perairan untuk parameter Dissolved Oxygent (DO), salinitas, suhu, pH, kecerahan, nitrit, Biological Oxygent Demand (BOD dan amonia menunjukkan bahwa lokasi penelitian layak dan sesuai untuk dijadikan sebagai tempat budi daya KJA. Akan tetapi, hal tersebut tidak berlaku untuk parameter nitrat. Berdasarkan hasil analisis dan verifikasi lapangan dengan pertimbangan aspek fisik dan keterjangkauan lokasi, maka Perairan Keneukai dapat direkomendasikan untuk pengembangan budi daya keramba jaring apung.
\end{abstract}

Kata kunci: Hidrodinamika, kualitas perairan, kesesuaian pembangunan, Keramba Jaring Apung (KJA) Offshore, Perairan Keneukai, Nangroe Aceh Darussalam.

\section{ABSTRACT}

Keneukai waters is one of the fishery resource producers in Weh Island, Nanggroe Aceh Darussalam. The number of fish species in these waters has decreased from 2008 to 2010. Research is conducted by Research Institute for Coastal Resources and Vulnerability (RICRV) in 2017 in order to determine the suitable location for Offshore Floating Marine Fish Cage aquaculture in Keneukai Waters. Data analysis is conducted in this research included currents, tides, bathymetry, and water quality analysis. Current velocity on the surface ranges from 0 to $0.9 \mathrm{~m} / \mathrm{s}$. Meanwhile, current speeds nearby the seafloor range from 0 to $0.74 \mathrm{~m} / \mathrm{s}$. The current vertical profile shows the Ekman Spiral mechanism that affects the vertical distribution of organic materials, and is dominated by tidal currents. The topography of Keneukai offshore coastal waters tends to ramp with a depth ranging from 0-72 meters. There is a significant depth change in some areas. The analysis results, sea water quality parametres including Dissolved Oxygent $(4,3 \mathrm{mg} / \mathrm{l})$, salinity $(31,2 \mathrm{ppt})$, temperature $\left(29,8^{\circ} \mathrm{C}\right), \mathrm{pH}(8,34)$, water transparency $(>10 \mathrm{~m})$, nitrite $(1,3 \mathrm{mg} / \mathrm{l})$, Biological Oxygent Demand $(0,98 \mathrm{mg} / \mathrm{l})$ ), and ammonia $(0,01 \mathrm{mg} / \mathrm{l}) \mathrm{indicate}$ that the research location is feasible and suitable to serve as an Offshore floating fish cage site. Based on the research results, considering the physical aspect and site accessibility, Keneukai offshore coastal waters can be recommended for the development of offshore floating net cage aquaculture.

Keywords: Hydrodynamics, water quality, suitability of development, offshore floating marine fish cage aquaculture, Nanggroe Aceh Darussalam.

Hidrodinamika dan Kualitas Perairan untuk Kesesuaian Pembangunan Keramba Jaring Apung (KJA) Offshore di Perairan Keneukai, Nangroe Aceh Darussalam - Koko Ondara, Guntur Adhi Rahmawan, Ulung Jantama Wisha dan Nia 


\section{PENDAHULUAN}

Secara geografis, Kota Sabang terletak di Pulau Weh yang berada di bagian paling barat Wilayah Negara Kesatuan Indonesia yang mempunyai posisi dan lokasi yang sangat strategis. Kota Sabang berbatasan dengan Selat Benggala di sebelah utara, Samudera Indonesia di sebelah selatan, Selat Malaka di sebelah timur, dan Samudera Hindia di sebelah barat. Berdasarkan analisis kerentanan lingkungan pulau, Pulau Weh termasuk ke dalam kategori pulau yang rentan. Dalam skala indeks 0-1, indeks kerentanan Pulau Weh adalah 0,61 (Husnayaen, 2008). Suatu daerah yang mempunyai tingkat kerentanan tinggi akan mempunyai peluang terjadinya bencana yang tinggi pula sehingga akan menurunkan minat wisatawan untuk berkunjung. Keneukai adalah sebuah kelurahan di Kota Madya Sabang, Pulau Weh, Provinsi Nanggroe Aceh Darussalam (NAD). Keneukai tepatnya berada di sebelah Selatan Pulau Weh, di antara kaki Gunung Cot Leumo Matee dan Gunung Berapi. Jumlah spesies ikan yang terdapat di perairan Keneukai mengalami penurunan dari tahun 2008 hingga 2010 (Rudi et al., 2012). Salah satu penyebab berkurangnya jumlah spesies tersebut adanya pemutihan karang. Selain faktor tersebut, jumlah populasi ikan berpengaruh terhadap jumlah zooplankton dan phytoplankton di suatu perairan (Andersson et al., 1978). Saat ini, perairan Keneukai digunakan oleh para nelayan setempat untuk menangkap ikan dan terdapat objek wisata air panas di Tempat Pelelangan Ikan (TPI). Seiring dengan perkembangan aktivitas manusia di daerah tersebut, berbagai faktor lingkungan dapat mempengaruhi kondisi perairan ini. Penelitian ini bertujuan menentukan lokasi yang tepat untuk usaha budidaya perairan Keramba Jaring Apung (KJA) di perairan Keneukai untuk mendukung program prioritas Kementerian Kelautan dan Perikanan terkait pembangunan pulau-pulau terluar dan kawasan perbatasan sebagai Sentra Kelautan dan Perikanan Terpadu (SKPT) yang berbasis spasial dengan menjadikan sektor kelautan dan perikanan sebagai penggerak utamanya.

\section{BAHAN DAN METODE}

Penelitian dilakukan di perairan Keneukai, Pulau Weh pada bulan Maret 2017. Pengukuran arus dan pasang surut dilakukan menggunakan ADCP selama 24 jam pada kordinat $95,312291^{\circ} \mathrm{BT} ; 5,775059^{\circ} \mathrm{LU}$. Titik pengambilan sampel perairan dilakukan di 11 titik pengamatan berdasarkan karakteristik perairan dan luasan daerah penelitian (Gambar 1). Pengukuran in situ dilakukan menggunakan Water Quality Checker TOA pada kedalaman 1 meter. Sementara itu, sampel air diambil dengan menggunakan botol Nansen pada kedalaman 1 meter. Pengawetan sampel air dilakukan melalui proses pendinginan (Ali et al., 2013) dan pengujian sampel dilakukan di Laboratorium Balai Riset dan Standarisasi Industri (Baristand) Banda Aceh. Posisi titik pengambilan sampel menggunakan GPS Garmin Montera dengan akurasi 3-15 meter. Parameter kimia dan fisika yang diamati adalah oksigen terlarut, salinitas, suhu, $\mathrm{pH}$, nitrat, kecerahan, turbiditas, nitrit, amonia dan BOD 5.

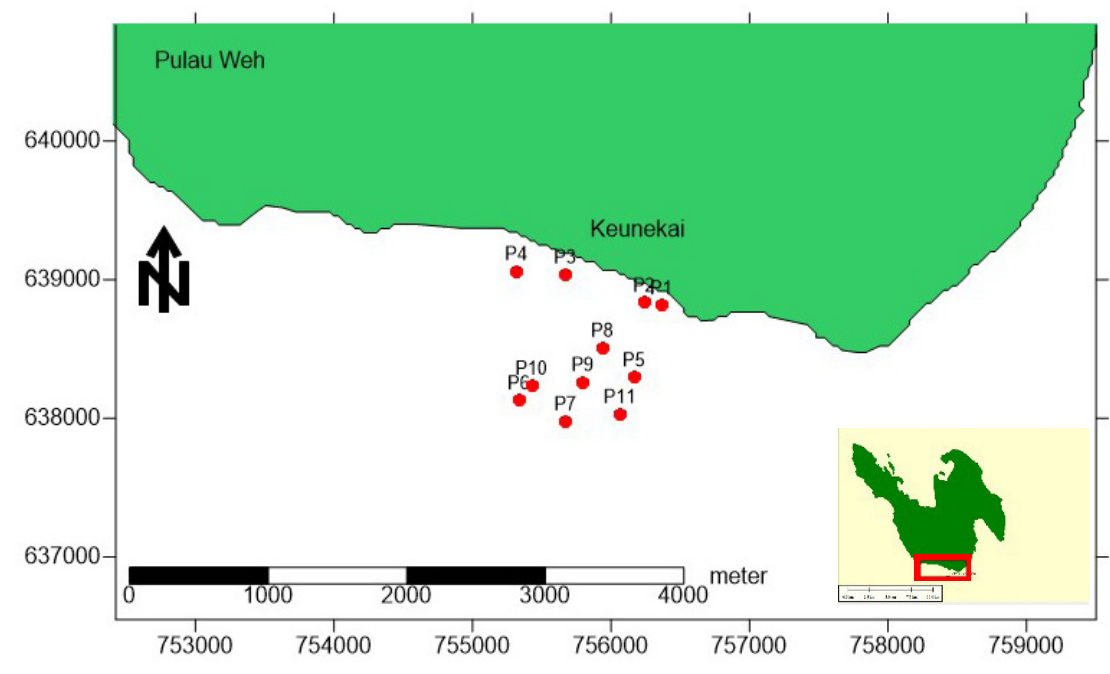

Gambar 1. Peta lokasi penelitian di Pulau Weh, Nangroe Aceh Darusalam.

Figure 1. Research Station Map in Weh Island, Nangro Aceh Darusalam.

JURNAL KELAUTAN NASIONAL, Vol. 12, No 2, Agustus 2017, Hal. 45-57 
Pengkuran batimetri dilakukan pada tanggal 14 Maret 2017 dengan menggunakan alat ukur batimetri single beam echosounder sedangkan analisis pasang surut dilakukan dengan menggunakan data sekunder yang diunduh dari website resmi Intergovernmental Oceanographic Commission of UNESCO yang menyediakan data tentang status operasional pasang surut (http://www.ioc-sealevelmonitoring.org/station. php?code=saba). Stasiun yang dipakai adalah stasiun Sabang dengan waktu perekaman selama bulan Maret 2017. Data yang dipilih adalah data perekaman pasang surut menggunakan sinyal sensor pressure (prs) yang merupakan pengukuran ketinggian air menggunakan prinsip tekanan. Sinyal sensor pressure merekam data pengamatan dengan interval waktu satu menit. Perhitungan data komponen harmonik pasang surut dilakukan dengan menggunakan Metode Admiralty (Supriyono dkk, 2015). Data hasil perekaman batimetri yang didapat merupakan data yang belum terkoreksi. Besarnya koreksi pasang surut adalah nilai kedalaman yang telah terkoreksi dengan tranducer, dikoreksi dengan nilai reduksi sesuai kedudukan permukaan laut pada waktu pengukuran (Simanjuntak et al., 2012). Reduksi pasang surut laut dirumuskan

$\mathrm{rt}=\mathrm{TWLt}-(\mathrm{MSL}+\mathrm{Zo})$

Tabel 1. Parameter perairan untuk untuk penentuan kesesuaian lokasi (Murtiono et al., 2016)

Table 1. Water parameters for determining location suitability (Murtiono et al., 2016)

\begin{tabular}{|c|c|c|c|c|}
\hline No & Parameter & Kisaran & $\begin{array}{l}\text { Angka } \\
\text { penilaian }\end{array}$ & Bobot \\
\hline 1 & Kedalaman & $\begin{array}{l}>10-20 \\
5-10 \\
<5 \text { atau }>20\end{array}$ & $\begin{array}{l}5 \\
3 \\
1 \\
\end{array}$ & 3 \\
\hline 2 & $\begin{array}{l}\text { Kecepatan arus } \\
(\mathrm{cm} / \mathrm{s})\end{array}$ & $\begin{array}{l}20-40 \\
10-20 \text { atau } 40-75 \\
<20 \text { atau }>75\end{array}$ & $\begin{array}{l}5 \\
3 \\
1\end{array}$ & 3 \\
\hline 3 & $\begin{array}{l}\text { Oksigen terlarut } \\
(\mathrm{mg} / \mathrm{l})\end{array}$ & $\begin{array}{l}\geq 5,0 \\
3,0 \geq x>5,0\end{array}$ & $\begin{array}{l}5 \\
3\end{array}$ & 3 \\
\hline 4 & Substrat dasar & $\begin{array}{l}<3,0 \\
\text { Pasir } \\
\text { Pasir berlumpur } \\
\text { Lumpur }\end{array}$ & $\begin{array}{l}1 \\
5 \\
3 \\
1 \\
\end{array}$ & 3 \\
\hline 5 & Salinitas (\%) & $\begin{array}{l}29-31 \\
27-29 \text { atau } 31-33 \\
<27 \text { atau }>33\end{array}$ & $\begin{array}{l}5 \\
3 \\
1\end{array}$ & 2 \\
\hline 6 & Suhu (0C) & $\begin{array}{l}28-30 \\
26-28 \text { atau } 30-31 \\
<26 \text { atau }>31\end{array}$ & $\begin{array}{l}1 \\
5 \\
3\end{array}$ & 2 \\
\hline$\overline{7}$ & $\mathrm{pH}$ & $\begin{array}{l}7,5-8,0 \\
7-7,5 \text { atau } 8-8,5\end{array}$ & $\begin{array}{l}5 \\
3 \\
\end{array}$ & 2 \\
\hline$\overline{8}$ & Ortofosfat (mg/l) & $\begin{array}{l}<7 \text { atau }>8,5 \\
\leq 0,015 \\
0,015>x \geq 0,8\end{array}$ & $\begin{array}{l}1 \\
5 \\
3\end{array}$ & 2 \\
\hline$\overline{9}$ & Nitrat (mg/l) & $\begin{array}{l}>0,8 \\
\leq 0,008 \\
0,008-0,4 \\
>0,4\end{array}$ & $\begin{array}{l}1 \\
5 \\
3 \\
1\end{array}$ & 1 \\
\hline$\overline{10}$ & Kecerahan (m) & $\begin{array}{l}\geq 5 \\
3-5 \\
<3\end{array}$ & $\begin{array}{l}5 \\
3 \\
1\end{array}$ & 1 \\
\hline 11 & Turbiditas (NTU) & $\begin{array}{l}\leq 5 \\
5-20 \\
>20\end{array}$ & $\begin{array}{l}5 \\
3 \\
1\end{array}$ & 1 \\
\hline 12 & Nitrit (mg/l) & $\begin{array}{l}0 \\
<0,1 \\
\geq 0,1\end{array}$ & $\begin{array}{l}3 \\
2 \\
1\end{array}$ & 1 \\
\hline$\overline{13}$ & Amonia (mg/l) & $\begin{array}{l}0-0,2 \\
0,2-0,5 \\
>0,5\end{array}$ & $\begin{array}{l}3 \\
2 \\
1\end{array}$ & 1 \\
\hline 14 & BOD5 (mg/l) & $\begin{array}{l}\leq 20 \\
20-45 \\
>45\end{array}$ & $\begin{array}{l}3 \\
2 \\
1\end{array}$ & 1 \\
\hline
\end{tabular}

Hidrodinamika dan Kualitas Perairan untuk Kesesuaian Pembangunan Keramba Jaring Apung (KJA) Offshore di Perairan Keneukai, Nangroe Aceh Darussalam - Koko Ondara, Guntur Adhi Rahmawan, Ulung Jantama Wisha dan Nia 
dengan rt adalah besarnya reduksi yang diberikan kedalaman pada waktu t; TWLt adalah Kedudukan muka laut pada waktu t; MSL adalah mean sea level; dan Zo adalah nilai muka air surutan dibawah MSL. Setelah itu, kedalaman sebenarnya dapat ditentukan dengan persamaan

$\mathrm{D}=\mathrm{Dt}-\mathrm{rt}$

dimana D adalah kedalaman sebenarnya; Dt adalah kedalaman dikoreksi tranducer; dan rt adalah besarnya reduksi yang diberikan kedalaman pada waktu t.

Faktor yang mempengaruhi budidaya perikanan (Shamsi, 2011) yaitu faktor lingkungan dan faktor kualitas perairan yang meliputi kedalaman, kecerahan, kecepatan arus, suhu, salinitas, $\mathrm{pH}$, oksigen terlarut, fosfat, nitrat, amoniak, dan silikat. Parameter perairan yang digunakan dalam penelitian ini beserta perhitungan bobot analisisnya ditunjukkan pada Tabel 1.

Matriks kesesuaian lingkungan perairan terhadap kemampuan (site capability) pada Tabel 1 umumnya terkait dengan lingkungan biogeofisik-kimia Pembobotan setiap faktor pembatas ditentukan berdasarkan besarnya pengaruh parameter tersebut terhadap peruntukannya. Kelas kesesuaian dibagi menjadi tiga kelas, yaitu sangat sesuai, sesuai dan tidak sesuai (Perez et al., 2005). Penentuan skor masingmasing kelas kesesuaian adalah sebagai berikut:

Kelas sangat sesuai $(\mathrm{S} 1)=>(\Sigma$ maks-x $)$

Kelas sesuai $(\mathrm{S} 2)=(\Sigma$ maks-2x $)-(\Sigma$ maks-x $)$

Kelas tidak sesuai $(\mathrm{S} 3)=<(\Sigma$ maks- $\mathrm{x})$

Untuk penentuan selang kelas kesesuaian menggunakan persamaan (Murtiono et al., 2016) :

$$
x=\frac{\sum_{\text {nilai maks }}-\Sigma_{\text {nilai minimal }}}{\text { jumlah kelas }}
$$

\section{HASIL DAN PEMBAHASAN}

\section{Kondisi Topografi}

Data yang didapatkan berupa raw data, yaitu data yang belum terkoreksi dengan kedalaman tranducer dan pasang surut. Raw data tersebut berisi informasi tentang waktu pemeruman (tanggal dan jam), posisi koordinat titik fixs perum X, Y dan data kedalaman hasil pembacaan tranducer. Hasil raw data tersebut merupakan data kedalaman terhadap perairan pada saat pengukuran. Untuk itu, diperlukan acuan untuk menggambarkan kondisi dasar perairan tersebut (Chart Datum) yang disajikan pada Gambar 2. Chart Datum digunakan sebagai dasar penentuan kedalaman batimetri (Khasanah, 2014).

Pengukuran pasut menghasilkan nilai MSL sebesar 182 $\mathrm{cm}$ dengan nilai $Z_{0} 20 \mathrm{~cm}$. Nilai chart datum sangat tergantung dengan besarnya nilai $Z_{0}$ (Satriadi, 2012). $\mathrm{Z}_{0}$ yang dipakai dalam perhitungan ini berdasarkan standard IHO (Khasanah et al., 2014) karena merupakan acuan standar yang dipakai secara internasional.

Kedalaman perairan Keneukai berkisar antara 0 sampai dengan 72 meter. Kedalaman yang sesuai untuk KJA berjarak 588 meter dari bibir pantai dan ke titik paling jauh dari daratan 865 meter, dengan kedalaman perairan sekitar 30 meter. Topografi dasar perairan termasuk landai dengan beberapa perubahan tertentu yang signifikan pada beberapa daerah. Topografi dasar perairan tersebut dapat dilihat dari model batimetri yang dihasilkan dengan garis kontur yang tidak sejajar terhadap garis kontur yang lain.

\section{Karakteristik hidrodinamika}

Kecepatan arus di permukaan (depth $=2,5$ meter) berkisar antara $0-0,9 \mathrm{~m} / \mathrm{s}$, kecepatan arus di kolom air (depth $=5,5$ meter) berkisar antara $0-0,85 \mathrm{~m} / \mathrm{s}$, kecepatan

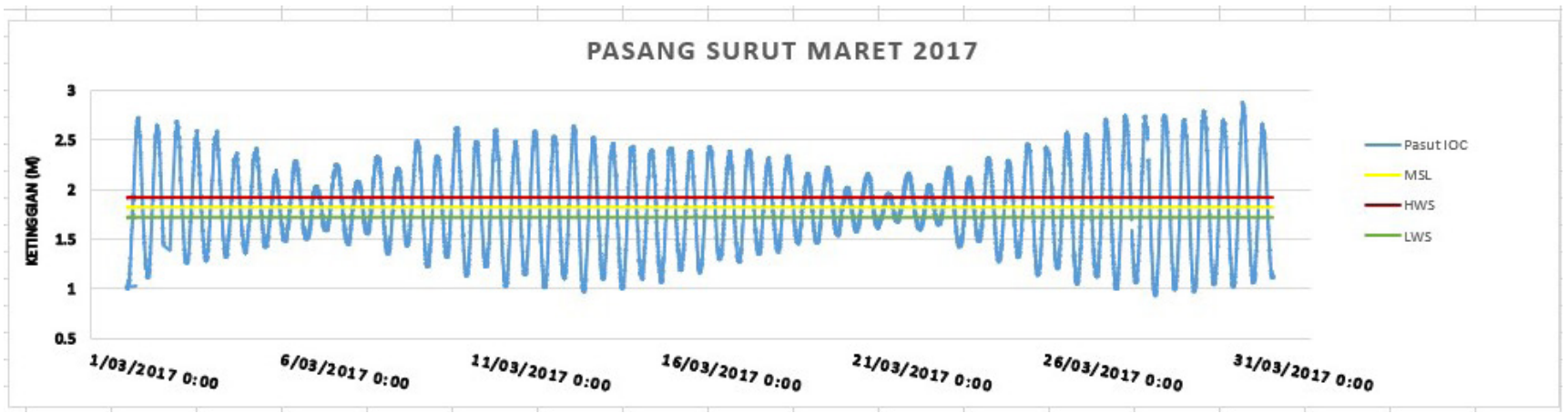

Gambar 2. Grafik pasang surut perairan Keneukai.

Figure 2. Tidal chart of Keneukai waters. 


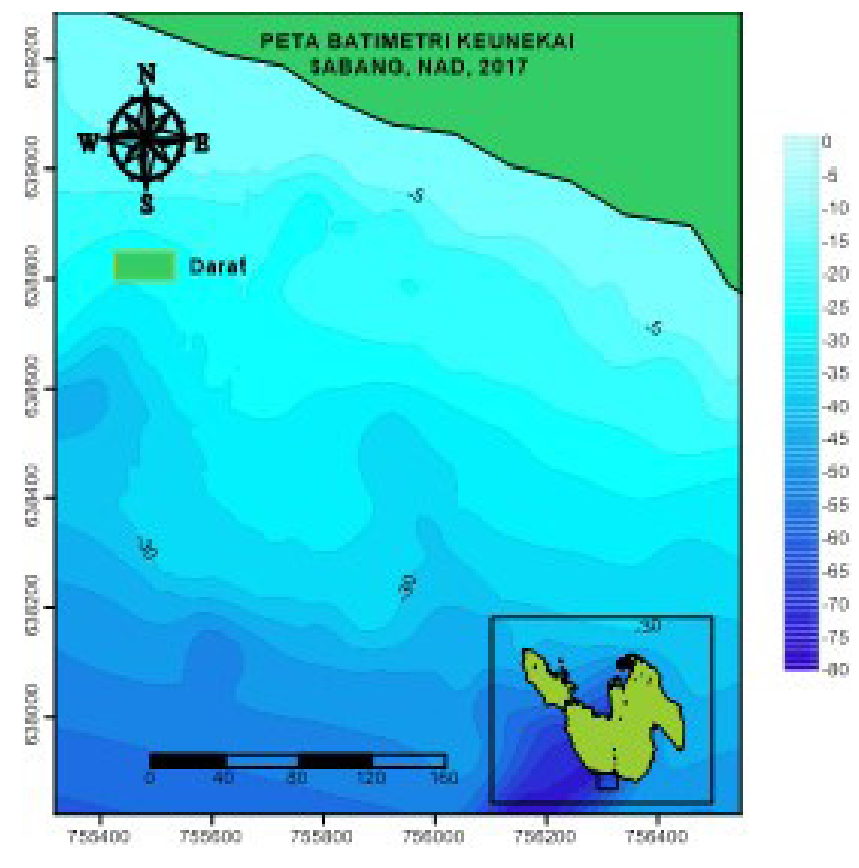

Gambar 3. Peta kedalaman perairan Keneukai Figure 3. Bathymetry Map of Keneukai Offshore Waters.

arus dekat dasar (depth $=8,5$ meter) berkisar antara 0-0,74 m/s. Di perairan Keneukai didominasi oleh arus pasang surut, dimana kecepatan arus meningkat pada saat surut, dan menurun pada saat pasang. Pada pengukuran tanggal 14 Maret 2017 pukul 15.00 WIB kecepatan arus mencapai maksimal yaitu $0,85 \mathrm{~m} / \mathrm{s}$.

Karena posisinya yang berbatasan langsung dengan Samudera Hindia dan Laut Andaman, hal tersebut menyebabkan karakteristik oseanografi yang terjadi tidak lepas dari pengaruh monsoon, Indian Ocean Dipole (IOD) dan fenomena ENSO yang terjadi di Samudera Hindia. Hal ini didukung juga oleh adanya pergerakan angin musiman yang berpengaruh dalam pembangkitan gelombang yang pada akhirnya mempengaruhi kecepatan arus yang terbentuk (Ilhamsyah et al., 2014).

Berdasarkan hasil pengolahan scatter plot arus terlihat bahwa di permukaan $(0,5 \mathrm{~m}$ dari permukaan) pergerakan komponen kecepatan arus lebih fluktuatif. Hal tersebut menunjukkan bahwa pengaruh angin masih sangat besar di permukaan, sehingga arus yang ditimbulkan bersifat lebih acak. Semakin ke dalam kecepatan arus mulai berkurang dan tidak menyebar, hal tersebut menandakan bahwa pengaruh angin akan berkurang seiring dengan bertambahnya kedalaman perairan, selain itu pengaruh dari hambatan dasar dan densitas juga berpengaruh dalam distribusi arus secara vertikal di perairan.

Profil arus horizontal pada tiap layer kedalaman menujukkan terjadinya Ekman pumping, dimana mekanisme tersebut berpengaruh terhadap distribusi material-mateial organik dari dasar menuju permukaan (Wisha et al., 2016). Siklus tersebut berpengaruh terhadap kesuburan perairan Keneukai. Distribusi nutrien secara vertikal pun dipengaruhi oleh mekanisme Ekman pumping tersebut. Sehingga membuat perairan Keneukai memiliki produktivitas primer yang tinggi (Mahadevan \& Archer, 2000), hal tersebut dibuktikan dengan kondisi ekosistem yang baik di wilayah tersebut. Ketika terjadi pasang surut, arus akan muncul meskipun tidak sebesar arus yang terjadi di laut lepas (Ondara et al., 2017).

Akan tetapi, hal yang sangat disayangkan adalah bahwa lokasi ini menjadi salah satu korban dari aktivitas pengeboman ikan yang berdampak pada kerusakan karang yang hingga saat ini masih mengalami rehabilitasi dan pembibitan karang. Masyarakat Keneukai sudah mulai sadar akan pentingnya menjaga kondisi lingkungan sehingga kebutuhan tangkapan

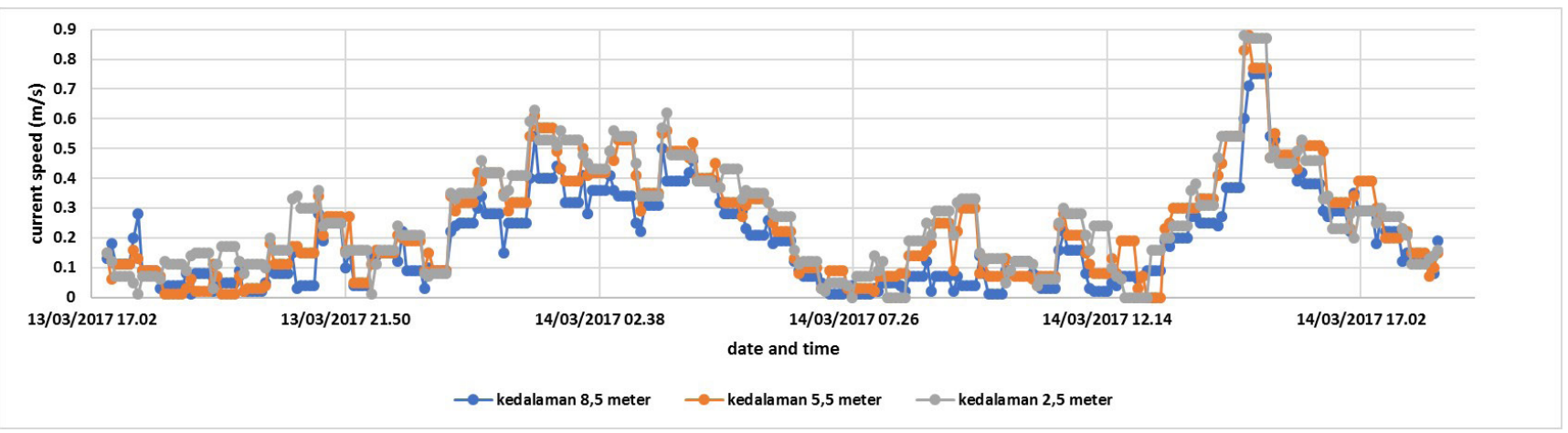

Gambar 4. Grafik kecepatan arus di kedalaman 2,5 m; 5,5 m dan 8,5 m.

Figure 4. Scatter plot the horizontal current velocity component of Keneukai waters at depth of 2,5 m; 5,5 $\mathrm{m}$ and 8,5 $\mathrm{m}$.

Hidrodinamika dan Kualitas Perairan untuk Kesesuaian Pembangunan Keramba Jaring Apung (KJA) Offshore di Perairan Keneukai, Nangroe Aceh Darussalam - Koko Ondara, Guntur Adhi Rahmawan, Ulung Jantama Wisha dan Nia 
ikan juga dapat terpenuhi hingga jangka waktu yang lebih lama.

Pergerakan arus vertikal didominasi oleh arah arus yang dominan menuju ke Tenggara, sehingga dapat diduga pada waktu tersebut, massa air dari Samudera Hindia lebih mendominasi dan mendorong menuju Selat Malaka.

Nilai kecepatan arus $U$ di permukaan berkisar antara -0,37-0,8 m/s dan kecepatan V berkisar antara -0,3-0,2 $\mathrm{m} / \mathrm{s}$ (Gambar 5). Pada kolom perairan, kecepatan U berkisar antara -0,3-0,6 m/s dan kecepatan $\mathrm{V}$ berkisar antara -0,3-0,2 m/s. Didekat dasar kecepatan arus menjadi lebih lemah dengan keceparan U berkisar antara $-0,15-0,5 \mathrm{~m} / \mathrm{s}$ dan dan kecepatan $\mathrm{V}$ berkisar antara $-0.15-0,15 \mathrm{~m} / \mathrm{s}$.

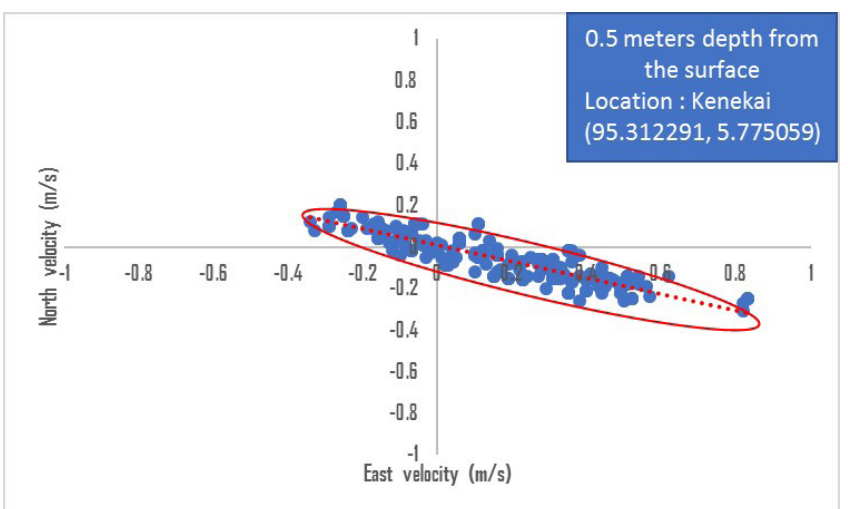

Gambar 5. Scatter plot komponen kecepatan arus horizontal perairan Keneukai di kedalaman 0,5 meter. Figure 5. Scatter plot the horizontal current velocity component of Keneukai waters at a depth of 0.5 meters.

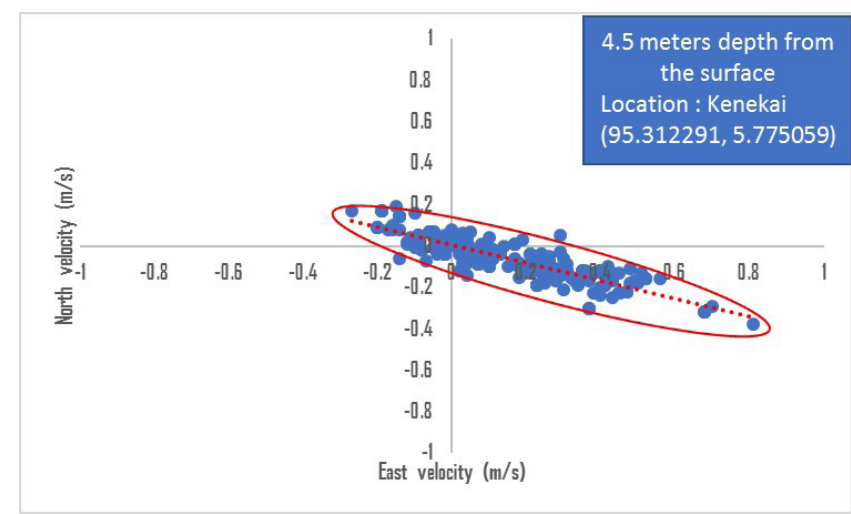

Gambar 6. Scatter plot komponen kecepatan arus horizontal perairan Keneukai di kedalaman 4,5 meter. Figure 6. Scatter plot the horizontal current velocity component of Keneukai waters at a depth of 4.5 meters.

\section{Sebaran kualitas perairan}

Hasil pengukuran kualitas kimia dan fisika perairan untuk masing-masing parameter ditampilkan pada tabel 2.

Hasil pengukuran dan analisis sampel air yang terdapat pada masing-masing stasiun pengamatan yang ditampilkan pada tabel 2 selanjutnya diinterpolasi menggunakan perangkat lunak Surfer untuk disusun menjadi sebuah peta tematik.

Derajat keasaman di perairan Keneukai berkisar 8,25 sampai 8,36 dengan rata-rata pada setiap titik pengamatan sebesar 8,33. Gambar 8 menunjukkan variasi $\mathrm{pH}$ pada setiap stasiun pengamatan dalam penelitian ini relatif rendah. Intensitas asam atau karakter dasar suatu larutan diindikasikan oleh $\mathrm{pH}$ dan aktivitas ion hidrogen. Perubahan $\mathrm{pH}$ air dapat menyebabkan berubahnya bau, rasa, dan warna. Kisaran $\mathrm{pH}$ untuk budidaya laut adalah 7,0-8,5 (KLH, 2004).

Perubahan konsentrasi nilai $\mathrm{pH}$ dalam perairan memiliki siklus harian, siklus ini merupakan fungsi karbondioksida. Jika perairan mengandung karbondioksida bebas dan ion karbonat maka $\mathrm{pH}$ cenderung asam dan $\mathrm{pH}$ akan kembali meningkat jika $\mathrm{CO}_{2}$ dan $\mathrm{HCO}_{3}$ mulai berkurang (Effendi, 2003). Pengukuran nilai salinitas perairan di perairan Keneukai (gambar 9) berkisar 30,8-31,4 ppt dengan nilai rata-rata sebesar 31,18 ppt. Nilai salinitas tidak menunjukkan perbedaan yang sangat signifikan. Hal tersebut diduga karena di sekitar perairan ini tidak terjadi kerusakan lingkungan. Perubahan salinitas secara drastis menyebabkan kerusakan sel-sel penting

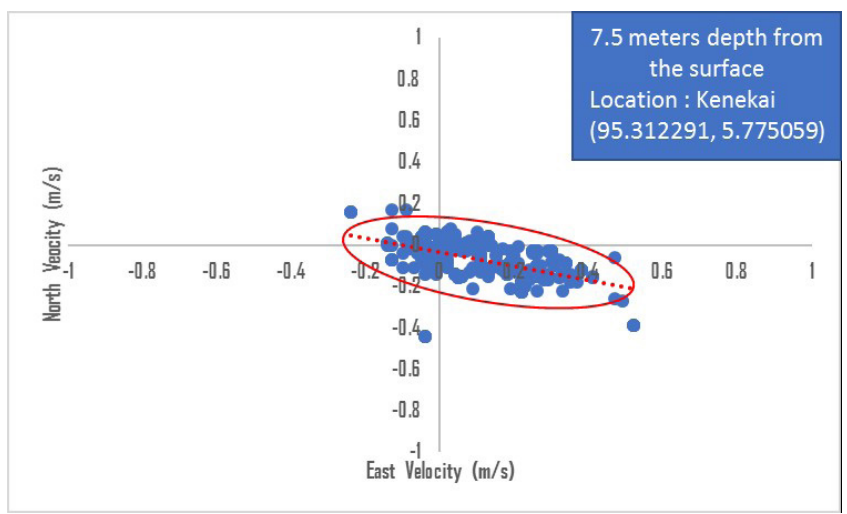

Gambar 7. Scatter plot komponen kecepatan arus horizontal perairan Keneukai di kedalaman 8,5 meter. Figure 7. Scatter plot the horizontal current velocity component of Keneukai waters at depth of 8.5 meters. 
Tabel 2. Parameter perairan untuk untuk penentuan kesesuaian lokasi

Table 2. Water parameters for determining location suitability

\begin{tabular}{|c|c|c|c|c|c|c|c|c|}
\hline Titik & Koordi & & Kedalaman & DO & Substrat & Salinitas & Suhu & pH \\
\hline & $\overline{\mathbf{L U}}$ & $\overline{\text { BT }}$ & (meter) & $(\mathrm{mg} / \mathrm{l})$ & dasar & (ppt) & $\left({ }^{\circ} \mathrm{C}\right)$ & \\
\hline$\overline{\mathrm{P} 1}$ & 5,7723 & 95,3074 & 4,3 & 4,3 & pasir & 31,4 & 29,8 & 8,34 \\
\hline P2 & 5,7719 & 95,3111 & 2,95 & 4,4 & pasir & 31,2 & 29,8 & 8,35 \\
\hline P3 & 5,7699 & 95,3131 & 0,7 & 4,4 & pasir & 31,1 & 29,9 & 8,34 \\
\hline P4 & 5,7711 & 95,3106 & 7,05 & 4,1 & pasir & 31,1 & 29,9 & 8,33 \\
\hline P5 & 5,7709 & 95,3063 & 26,24 & 4,2 & pasir & 31 & 29,9 & 8,34 \\
\hline P6 & 5,7696 & 95,3098 & 44,77 & 4,3 & pasir & 31,4 & 29,8 & 8,34 \\
\hline P7 & 5,7676 & 95,3122 & 46,49 & 4,4 & pasir & 31,2 & 29,9 & 8,35 \\
\hline P8 & 5,7694 & 95,3065 & 26,38 & 4,3 & pasir & 30,8 & 29,8 & 8,35 \\
\hline P9 & 5,7685 & 95,3056 & 27,09 & 4,2 & pasir & 31,3 & 29,4 & 8,34 \\
\hline P10 & 5,8978 & 95,3424 & 39,15 & 4,3 & pasir & 31,4 & 29,8 & 8,29 \\
\hline P11 & 5,8954 & 95,3458 & 44,28 & 4,4 & pasir & 31,4 & 29,8 & 8,25 \\
\hline P12 & 5,7723 & 95,3074 & 25,94 & 4,7 & pasir & 30,8 & 29,5 & 8,36 \\
\hline
\end{tabular}

lanjutan Tabel 2

\begin{tabular}{lllllllll}
\hline Titik & \multicolumn{2}{l}{ Koordinat } & $\begin{array}{l}\text { BOD } \\
\text { (mg/l) }\end{array}$ & $\begin{array}{l}\text { Nitrat } \\
(\mathbf{m g} / \mathbf{l})\end{array}$ & $\begin{array}{l}\text { Kecerahan } \\
(\mathbf{m e t e r})\end{array}$ & $\begin{array}{l}\text { Turbiditas } \\
\mathbf{( N T U )}\end{array}$ & $\begin{array}{l}\text { Nitrit } \\
(\mathbf{m g} / \mathbf{l})\end{array}$ & $\begin{array}{l}\text { Amonia } \\
(\mathbf{m g} / \mathbf{l})\end{array}$ \\
\hline P1 & 5,7723 & 95,3074 & 0,89 & 1,6 & 4,3 & 0,1 & 0,006 & 0,01 \\
P2 & 5,7719 & 95,3111 & 0,69 & 1,3 & 2,95 & 1,8 & 0,009 & 0,02 \\
P3 & 5,7699 & 95,3131 & 0,49 & 1,4 & 0,7 & 0,6 & 0,008 & 0,02 \\
P4 & 5,7711 & 95,3106 & 0,59 & 1,5 & 7 & 0,9 & 0,008 & 0,03 \\
P5 & 5,7709 & 95,3063 & 0,89 & 1,1 & $>10$ & 0,1 & 0,005 & 0,01 \\
P6 & 5,7696 & 95,3098 & 0,98 & 1,3 & $>10$ & 0,1 & 0,008 & 0,00 \\
P7 & 5,7676 & 95,3122 & 0,79 & 1,3 & $>10$ & 0,1 & 0,008 & 0,00 \\
P8 & 5,7694 & 95,3065 & 0,69 & 1,4 & $>10$ & 1,9 & 0,007 & 0,00 \\
P9 & 5,7685 & 95,3056 & 0,59 & 1,1 & $>10$ & 1,1 & 0,003 & 0,00 \\
P10 & 5,8978 & 95,3424 & 0,59 & 1,2 & $>10$ & 1,3 & 0,017 & 0,00 \\
P11 & 5,8954 & 95,3458 & 0,49 & 1,4 & $>10$ & 1,2 & 0,007 & 0,00 \\
P12 & 5,7723 & 95,3074 & 0,49 & 1,2 & $>10$ & 2,3 & 0,003 & 0,00 \\
\hline
\end{tabular}

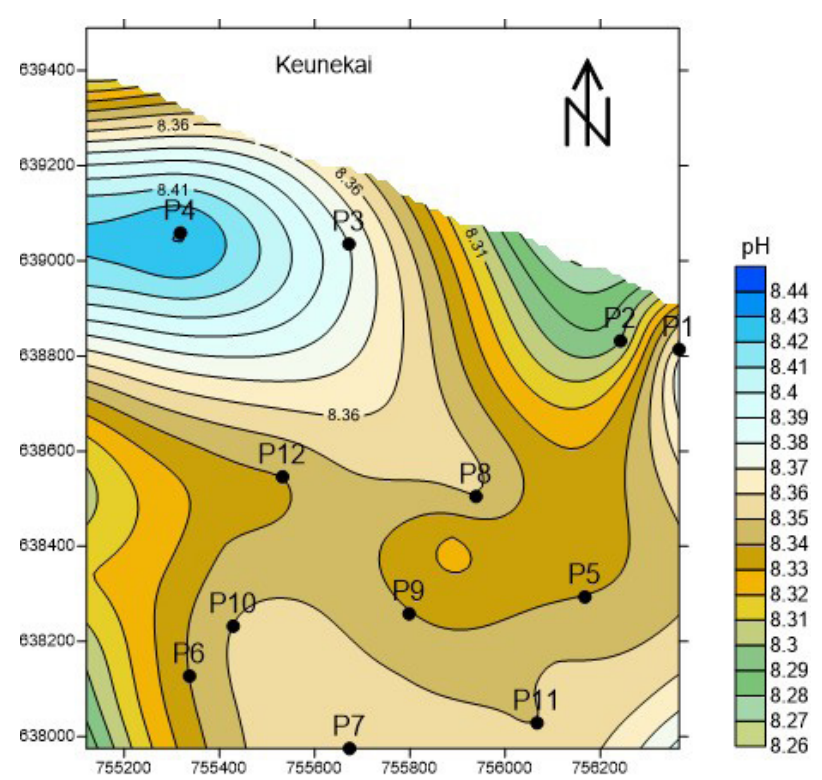

Gambar 8. Derajat keasaman (pH) di Perairan Keneukai. Figure 8. Degree of Acidity $(p H)$ in Keneukai Waters. yang berkembang secara fisiologis dari sistem perkembangan organisme dan dapat menyebabkan pemutihan karang (Zamani et al., 2016).

Jumlah limbah masyarakat yang mencemari perairan juga cukup sedikit. Kondisi ini ditunjang dengan sadarnya masyarakat akan lingkungan sekitar. Salinitas berpengaruh terhadap tekanan osmotik media (Wirasatriya et al., 2004) sehingga penting untuk dijaga keseimbangan osmolaritas cairan internal dan eksternal. Khusus untuk budidaya perikanan, nilai salinitas yang dibutuhkan sesuai dengan jenis ikan yang akan dibudidaya, karena ikan tertentu membutuhkan salinitas dengan nilai tertentu. Hasil pemetaan (Gambar 5) juga menunjukkan semua lokasi penelitian layak untuk dikembangkan budidaya perikanan (Tabel 1).

Suhu perairan berhubungan dengan kemampuan inflitrasi sinar matahari, waktu dan lokasi (Effendi, 2003). Pernyataan ini didukung bahwa air lebih lambat

Hidrodinamika dan Kualitas Perairan untuk Kesesuaian Pembangunan Keramba Jaring Apung (KJA) Offshore di Perairan Keneukai, Nangroe Aceh Darussalam - Koko Ondara, Guntur Adhi Rahmawan, Ulung Jantama Wisha dan Nia 


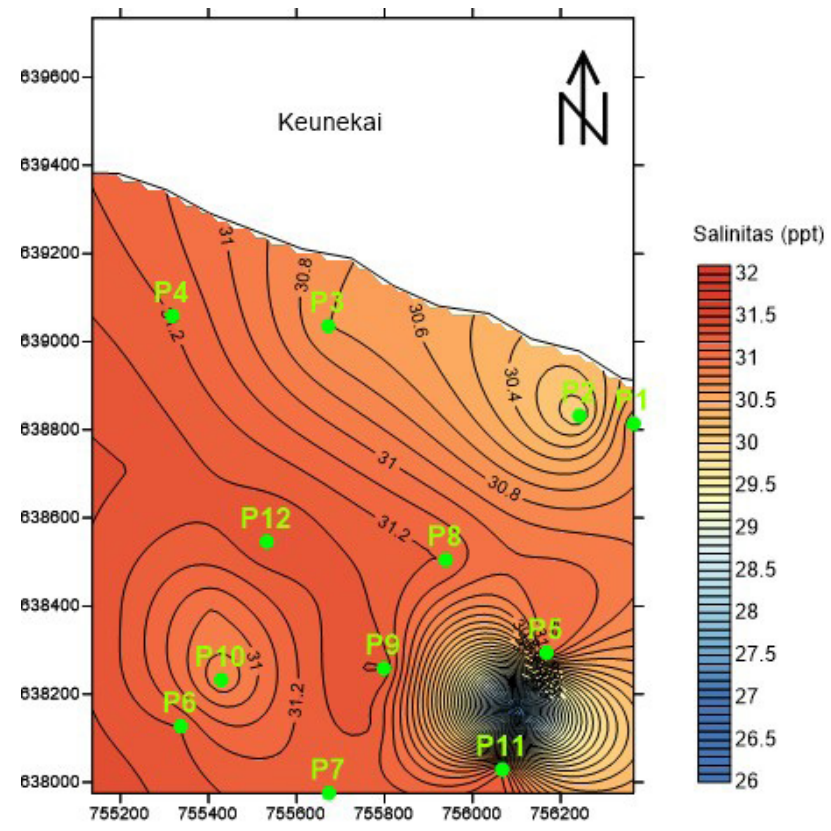

Gambar 9. Sebaran nilai salinitas di perairan Keneukai.

Figure 9. Distribution of salinity in Keneukai waters.

menyerap panas tetapi dapat menyimpan panas lebih lama bila dibandingkan dengan daratan (Basmi, 2000). Suhu perairan di daerah perairan Keneukai (Gambar 6) berkisar antara $29,40{ }^{\circ} \mathrm{C}$ sampai dengan $29,9{ }^{\circ} \mathrm{C}$ dengan nilai rata-rata sebesar $29,78^{\circ} \mathrm{C}$. Perbedaan suhu perairan ini berhubungan dengan adanya selisih waktu dalam pengukuran in situ selama proses penelitian.

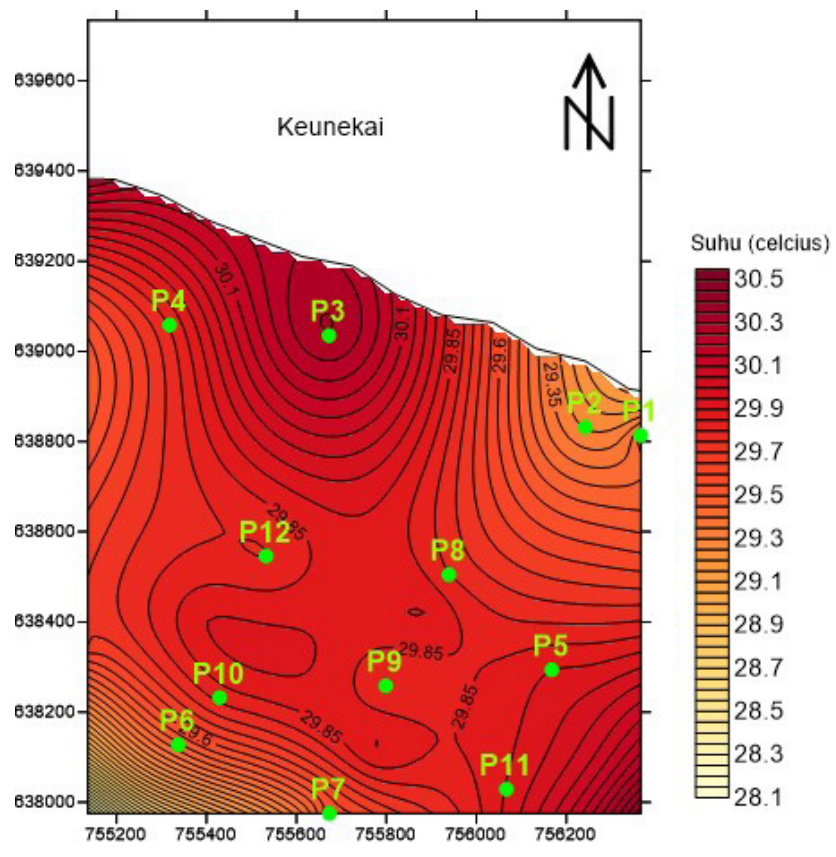

Gambar 10. Sebaran temperatur di perairan Keneukai.

Figure 10. Distribution of temperature in Keneukai waters.

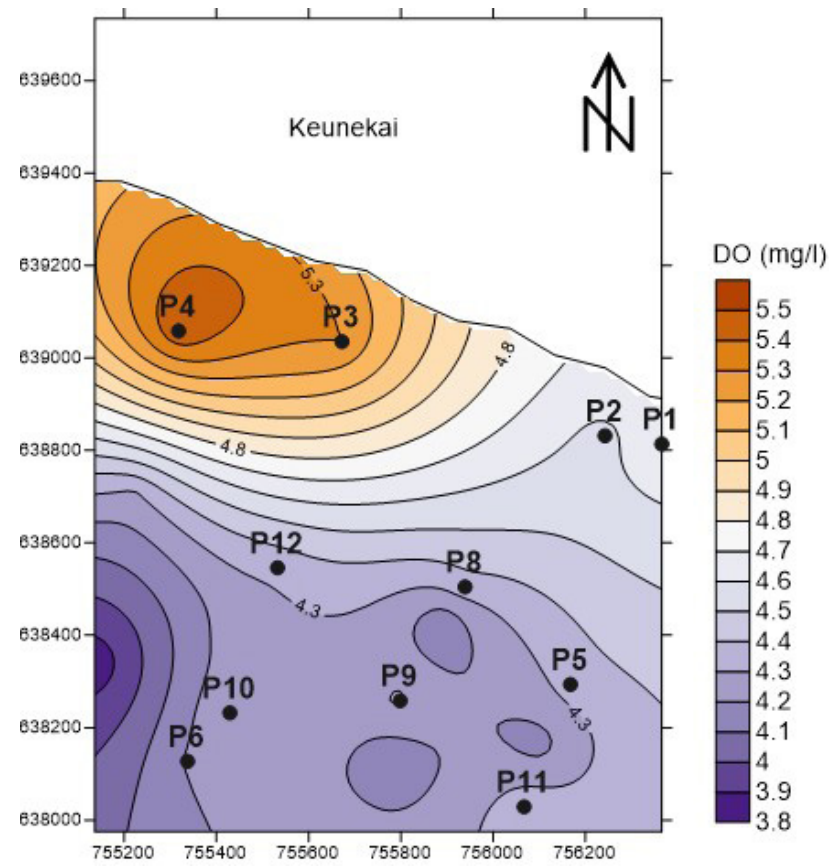

Gambar 11. Sebaran oksigen terlarut (DO) di perairan Keneukai.

Figure 11. Distribution of dissolved oxygen (DO) in Keneukai waters.

Pada daerah perairan Keneukai yang terbuka, akan terjadi perubahan suhu yang cenderung stabil (Gambar 10) dan tidak terlalu banyak mengalami perubahan dikarenakan terjadinya perubahan massa air di daerah selat.

Oksigen terlarut merupakan parameter yang sangat penting dalam budidaya perikanan. Peningkatan suhu, salinitas dan tekanan menyebabkan penurunan oksigen. Bagi ikan, untuk sekedar hidup diperlukan oksigen 1 $\mathrm{mg} / \mathrm{l}$, untuk dapat tumbuh dan berkembang minimal 3 $\mathrm{mg} / \mathrm{l}$, dan untuk budidaya perikanan, oksigen terlarut yang optimal 5-8 mg/l (Mayunar et al., 1995). Hasil penelitian (Gambar 11) menunjukkan nilai oksigen terlarut berkisar $4,12 \mathrm{mg} / 1$ sampai dengan $4,70 \mathrm{mg} / 1$. Jika mengacu pada Kepmen LH No.51 tahun 2004 tentang baku mutu air laut, kondisi ini kurang baik karena oksigen terlarut di bawah $5 \mathrm{mg} / \mathrm{l}$. Nilai oksigen terlarut di daerah pantai terlihat lebih tinggi karena berdasarkan pengamatan visual, daerah pantai tersebut banyak jenis tumbuhan perairan dan vegetasi pantai yang beraneka ragam. Kadar oksigen terlarut dalam suatu perairan akan naik karena proses fotosintesis semakin meningkat. Cara untuk menanggulangi jika kelebihan kadar oksigen terlarut adalah dengan cara menaikkan suhu perairan, menambah kedalaman air dan mengurangi bahan-bahan organik dalam air.

Pengamatan secara visual menunjukkan bahwa perairan 


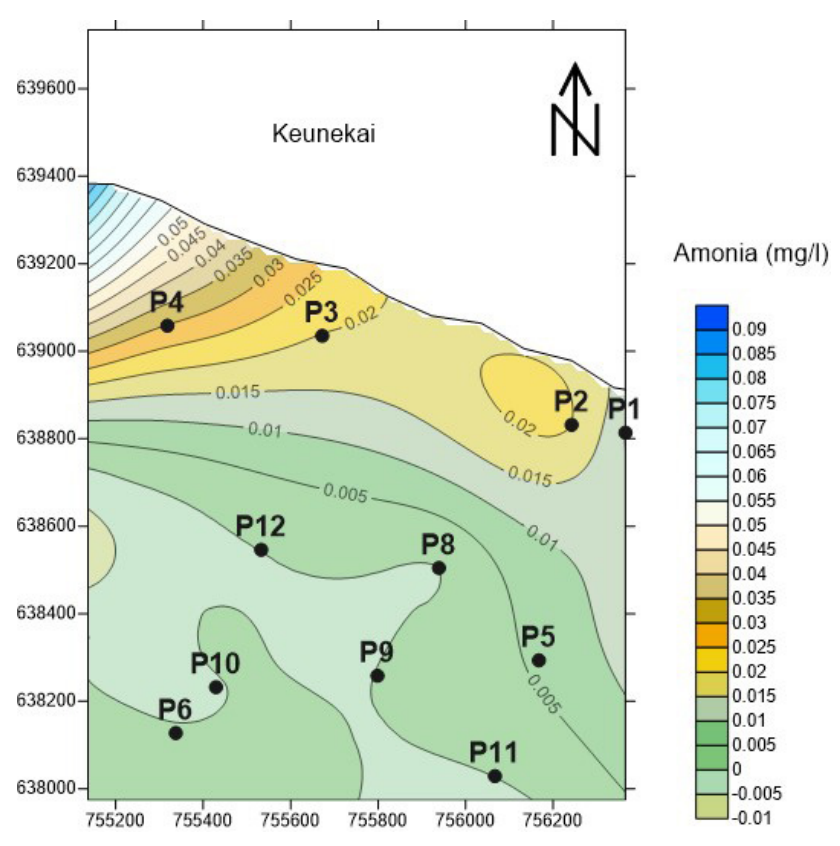

Gambar 12. Sebaran amonia di perairan Keneukai.

Figure 12. The distribution of ammonia in Keneukai waters.

Keneukai dalam kondisi baik dan jernih. Perbedaan hasil pengukuran dan pengamatan visual mungkin disebabkan perbedaan perlakuan sampel dan kualitas alat yang digunakan. Seharusnya jika nilai kandungan oksigen terlarut bervariasi, diduga karena adanya pergerakan dan pencampuran massa air serta siklus harian arus. Wilayah perairan yang terbuka memiliki pergerakan massa air yang lebih baik sehingga memungkinkan terjadinya pencampuran massa air. Kondisi tersebut menyebabkan perbedaan kandungan oksigen terlarut jika waktu pengukuran tidak sama.

Hasil penelitian terhadap parameter Amonia di perairan Keneukai (Gambar 12) menunjukkan nilai yang berkisar antara $<0,0001$ hingga $0,01 \mathrm{mg} / \mathrm{l}$. Analisis di laboratorium menunjukkan bahwa nilai amonia kurang dari $0,0001 \mathrm{mg} / 1$, dikarenakan terbatasnya ketelitian alat yang hanya bisa mengukur sampai ketelitian $0,0001 \mathrm{mg} / \mathrm{l}$. Nilai baku mutu yang disarankan untuk biota laut adalah 0,3. Nilai Sumber amonia di perairan adalah pemecahan nitrogen organik dan nitrogen anorganik yang terdapat di tanah dan air yang berasal dari dekomposisi bahan organik oleh mikroba dan jamur (Effendi, 2003). Kondisi perairan yang mengalami jumlah amonia lebih kecil yang tidak sesuai standar di perairan Keunekai akan mengakibatkan terjadinya penyempitan insang, penurunan jumlah sel darah, penurunan kadar oksigen dalam darah dan mengurangi ketahanan fisik dan daya tahan terhadap penyakit (Sutomo, 1989)

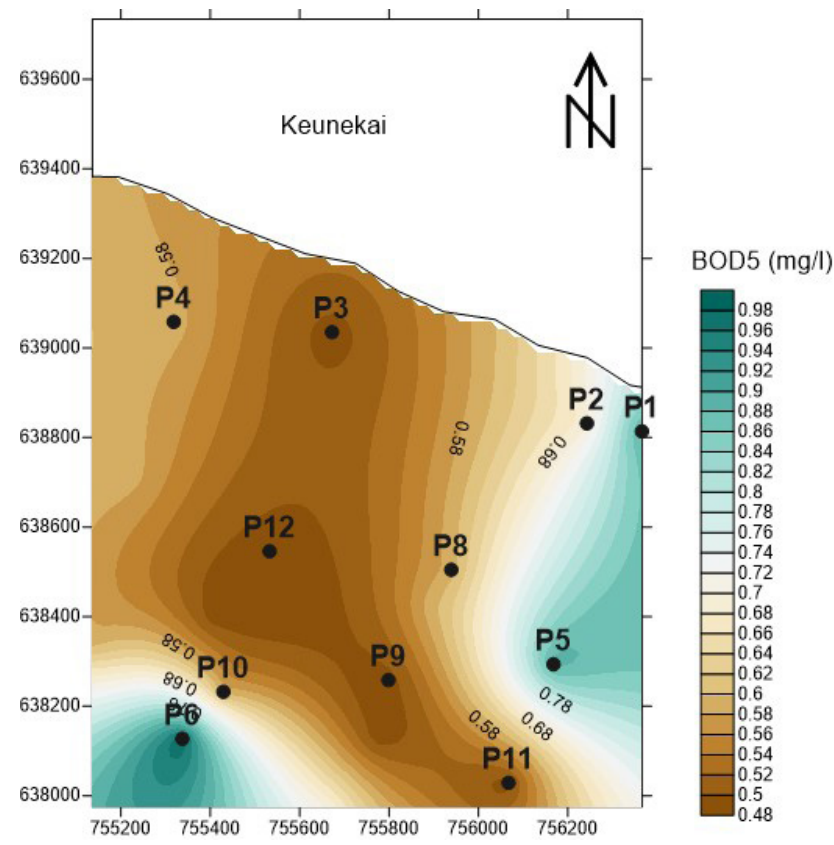

Gambar 13. Sebaran Biochemical Oxygen Demand (BOD) di perairan Keneukai.

Figure 13. Distribution of Biochemical Oxygen Demand $(B O D)$ in Keneukai waters.

Biochemical Oxygen Demand (BOD) merupakan gambaran kadar oksigen yang dibutuhkan oleh mikroba aerob untuk mengoksidasi bahan organik menjadi karbondioksida dan air (Davis et al., 1991). Konsentrasi parameter BOD5 di perairan Keneukai berkisar 0,49 hingga $0,98 \mathrm{mg} / 1$. Nilai BOD di perairan alami berkisar antara $0,5-0,7 \mathrm{mg} / 1$, sedangkan perairan

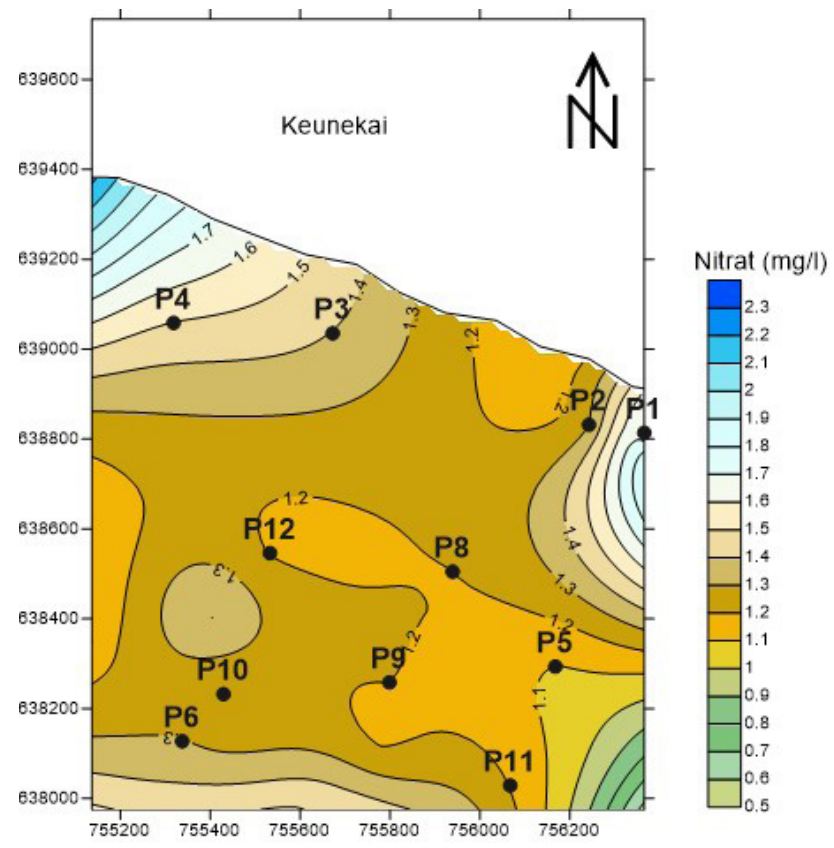

Gambar 14. Sebaran Nitrat di perairan Keneukai.

Figure 14. Distribution of Nitrate in Keneukai waters.

Hidrodinamika dan Kualitas Perairan untuk Kesesuaian Pembangunan Keramba Jaring Apung (KJA) Offshore di Perairan Keneukai, Nangroe Aceh Darussalam - Koko Ondara, Guntur Adhi Rahmawan, Ulung Jantama Wisha dan Nia 


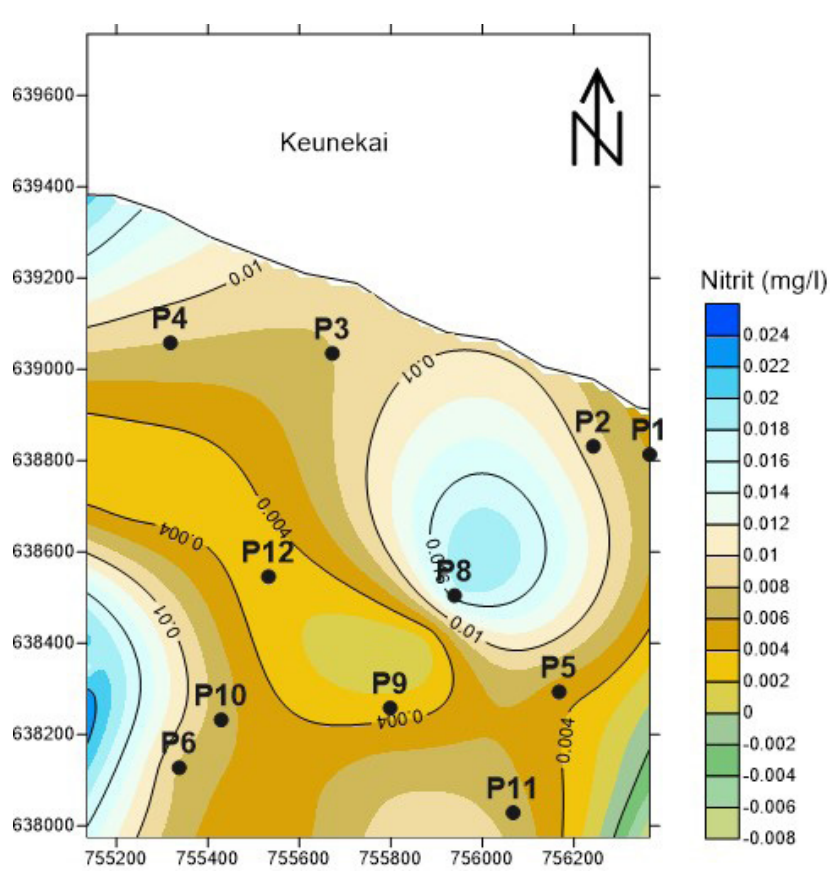

Gambar 15. Sebaran Nitrit di Perairan Keneukai.

Figure 15. Distribution of Nitrite in Keneukai Waters.

dengan kadar lebih dari $10 \mathrm{mg} / 1$ dianggap telah mengalami pencemaran (Jeffries et al., 1994). Menurut baku mutu air laut untuk biota laut adalah kurang dari $20 \mathrm{mg} / \mathrm{l}$ (KLH, 2004). Dengan nilai BOD tersebut, maka perairan Keunekai layak untuk dijadikan tempat budidaya perikanan.

Pengukuran konsentrasi nitrat memperlihatkan nilai yang berkisar antara $1,1 \mathrm{mg} / 1$ sampai dengan $1,6 \mathrm{mg} / 1$ dengan rata-rata sebesar $1,31 \mathrm{mg} / 1$ (Gambar 14). Nilai nitrat menunjukkan hasil yang berada di atas ambang batas kesesuaian dan kurang baik untuk budidaya perikanan. Kadar nitrat si perairan sebaiknya kurang dari 1,0 mg/l (Wedemeyer, 1996) dan kurang dari $0,008 \mathrm{mg} / 1 \mathrm{menurut}$ baku mutu air laut untuk biota laut (KLH, 2004).

Nilai variabel nitrit memperlihatkan nilai yang bervariasi antara $0,003 \mathrm{mg} / 1$ sampai dengan $0,017 \mathrm{mg} / 1$ dengan nilai rata-rata sebesar $0,007 \mathrm{mg} / 1$ (Gambar 15). Nitrit bersifat tidak stabil di perairan alami dengan keberadaan oksigen. Nilai nitrit di perairan Keneukai menunjukkan bentuk peralihan (intermediate) antara ammonia dan nitrat (nitrifikasi) dan antara nitrat dengan gas nitrogen (denitrifikasi).

Hasil penelitian menunjukkan kisaran nilai turbiditas berkisar 0,1 NTU sampai dengan 2,3 NTU (Gambar 15). Nilai kekeruhan tersebut menunjukkan bahwa perairan Keunekai layak untuk dijadikan sebagai lokasi budidaya perikanan. Nilai kekeruhan yang relatif rendah menunjukkan rendahnya tingkat sedimentasi di kawasan tersebut. Nilai turbiditas juga menunjukkan rendahnya nilai kekeruhan dari padatan organik dan anorganik yang tersuspensi di perairan Keneukai. Kekeruhan tersebut pada umumnya berasal dari erosi tanah, limbah pertambangan, limbah rumah tangga dan buangan limbah industri lainnya (Beveridge, 2004).

Kecerahan menunjukkan kemampuan infiltrasi cahaya ke dalam perairan. Tingkat infiltrasi cahaya dipengaruhi oleh partikel yang tersuspensi dan terlarut dalam air. Nilai kecerahan di sekitar perairan Keneukai antara 0,7 hingga lebih dari 10 meter. Hasil tersebut menunjukkan bahwa perairan tersebut masih layak untuk dijadikan sebagai tempat budidaya perikanan.

Tabel 3. Rekapitulasi nilai bobot pada setiap titik pengamatan

Table 3. Recapitulation of weight values at each observation point

\begin{tabular}{|c|c|c|c|c|c|c|c|c|c|c|c|c|}
\hline \multirow[t]{2}{*}{ Parameter } & \multicolumn{12}{|c|}{ Titik Pengamatan } \\
\hline & $\overline{\mathbf{P 1}}$ & $\overline{\mathbf{P 2}}$ & $\overline{\text { P3 }}$ & $\overline{\mathbf{P 4}}$ & $\overline{\text { P5 }}$ & $\overline{\text { P6 }}$ & $\overline{\text { P7 }}$ & $\overline{\mathbf{P 8}}$ & P9 & $\mathbf{P 1 0}$ & $\overline{\text { P11 }}$ & P12 \\
\hline Kedalaman (m) & 1 & 1 & 1 & 3 & 1 & 1 & 1 & 1 & 1 & 1 & 1 & 1 \\
\hline $\mathrm{DO}(\mathrm{mg} / \mathrm{l})$ & 3 & 3 & 3 & 3 & 3 & 3 & 3 & 3 & 3 & 3 & 3 & 3 \\
\hline Substrat dasar & 5 & 5 & 5 & 5 & 5 & 5 & 5 & 5 & 5 & 5 & 5 & 5 \\
\hline Salinitas (ppt) & 3 & 3 & 3 & 3 & 3 & 3 & 3 & 3 & 3 & 3 & 3 & 5 \\
\hline Suhu (C) & 5 & 5 & 5 & 5 & 5 & 5 & 5 & 5 & 5 & 5 & 5 & 5 \\
\hline $\mathrm{pH}$ & 3 & 3 & 3 & 3 & 3 & 3 & 3 & 3 & 3 & 3 & 3 & 3 \\
\hline Nitrat (mg/l) & 1 & 1 & 1 & 1 & 1 & 1 & 1 & 1 & 1 & 1 & 1 & 1 \\
\hline Kecerahan (m) & 3 & 1 & 1 & 5 & 5 & 5 & 5 & 5 & 5 & 5 & 5 & 5 \\
\hline Turbiditas (NTU) & 5 & 5 & 5 & 5 & 5 & 5 & 5 & 5 & 5 & 5 & 5 & 5 \\
\hline Nitrit (mg/l) & 2 & 2 & 2 & 2 & 2 & 2 & 2 & 2 & 2 & 2 & 2 & 2 \\
\hline Amonia (mg/l) & 3 & 3 & 3 & 3 & 3 & 3 & 3 & 3 & 3 & 3 & 3 & 3 \\
\hline $\mathrm{BOD}(\mathrm{mg} / \mathrm{l})$ & 3 & 3 & 3 & 3 & 3 & 3 & 3 & 3 & 3 & 3 & 3 & 3 \\
\hline Nilai Total & 37 & 35 & 35 & 41 & 39 & 39 & 39 & 39 & 39 & 39 & 39 & 41 \\
\hline
\end{tabular}


Tabel 4. Rekapitulasi hasil perkalian bobot dan skor pada setiap titik pengamatan

Table 4. Recapitulation of the result of multiplication of weights and scores at each observation point

\begin{tabular}{|c|c|c|c|c|c|c|c|c|c|c|c|c|}
\hline \multirow[t]{2}{*}{ Parameter } & \multicolumn{12}{|c|}{ Titik Pengamatan } \\
\hline & $\overline{\mathbf{P 1}}$ & $\overline{\mathbf{P 2}}$ & $\overline{\mathbf{P 3}}$ & $\overline{\mathbf{P 4}}$ & $\overline{\text { P5 }}$ & $\overline{\mathbf{P 6}}$ & $\overline{\mathbf{P 7}}$ & $\overline{\mathbf{P 8}}$ & $\overline{\mathbf{P 9}}$ & $\overline{\mathbf{P 1 0}}$ & $\overline{\text { P11 }}$ & $\overline{\mathbf{P 1 2}}$ \\
\hline Kedalaman (m) & 3 & 3 & 3 & 9 & 3 & 3 & 3 & 3 & 3 & 3 & 3 & 3 \\
\hline DO (mg/l) & 9 & 9 & 9 & 9 & 9 & 9 & 9 & 9 & 9 & 9 & 9 & 9 \\
\hline Substrat dasar & 15 & 15 & 15 & 15 & 15 & 15 & 15 & 15 & 15 & 15 & 15 & 15 \\
\hline Salinitas (ppt) & 9 & 9 & 9 & 9 & 9 & 9 & 9 & 9 & 9 & 9 & 9 & 15 \\
\hline Suhu (C) & 15 & 15 & 15 & 15 & 15 & 15 & 15 & 15 & 15 & 15 & 15 & 15 \\
\hline $\mathrm{pH}$ & 9 & 9 & 9 & 9 & 9 & 9 & 9 & 9 & 9 & 9 & 9 & 9 \\
\hline Nitrat (mg/l) & 3 & 3 & 3 & 3 & 3 & 3 & 3 & 3 & 3 & 3 & 3 & 3 \\
\hline Kecerahan (m) & 9 & 3 & 3 & 15 & 15 & 15 & 15 & 15 & 15 & 15 & 15 & 15 \\
\hline Turbiditas (NTU) & 15 & 15 & 15 & 15 & 15 & 15 & 15 & 15 & 15 & 15 & 15 & 15 \\
\hline Nitrit (mg/l) & 6 & 6 & 6 & 6 & 6 & 6 & 6 & 6 & 6 & 6 & 6 & 6 \\
\hline Amonia (mg/l) & 9 & 9 & 9 & 9 & 9 & 9 & 9 & 9 & 9 & 9 & 9 & 9 \\
\hline $\mathrm{BOD}(\mathrm{mg} / \mathrm{l})$ & 9 & 9 & 9 & 9 & 9 & 9 & 9 & 9 & 9 & 9 & 9 & 9 \\
\hline Nilai Total & 111 & 105 & 105 & 123 & 117 & 117 & 117 & 117 & 117 & 117 & 117 & 123 \\
\hline
\end{tabular}

Dari hasil perhitungan, diperoleh nilai selang kelas sebesar 6 sehingga nilai kesesuaian untuk masingmasing kelas sebagai berikut: perairan dengan kategori sangat sesuai (S1) mempunyai nilai rentang lebih besar $>118,5$; perairan dengan kategori cukup sesuai (S2) mempunyai rentang nilai antara 118,5-114,0; perairan dengan kategori sesuai bersyarat (S3) mempunyai rentang nilai antara $114,0-110,0$; dan perairan dengan kategori tidak sesuai $(\mathrm{N})$ memiliki nilai yang lebih kecil dari < 109,5.

Berdasarkan hasil perhitungan tabel 4 , maka tingkat kesesuaian pada setiap titik pengamatan terlihat pada tabel 5.

Dari hasil penentuan tingkat kesesuaian perairan sebagai lokasi budidaya perairan KJA, terlihat bahwa titik P4 hingga titik P12 termasuk dalam kategori sesuai dan layak sebagai lokasi budidaya. Titik P1 masuk ke dalam kategori sesuai dengan beberapa syarat dan kondisi tertentu, sedangkan titik P2 dan P3 tidak layak dijadikan sebagai lokasi budidaya perikanan KJA.

\section{KESIMPULAN DAN SARAN}

Profil kecepatan arus menunjukkan bahwa di dasar perairan berkisar antara $0-0,74 \mathrm{~m} / \mathrm{s}$. Topografi Perairan Keneukai termasuk landai dengan kedalaman berkisar 0-72 meter dan terdapat perubahan kedalaman yang signifikan di sejumlah area. Hasil analisis perairan untuk parameter Dissolved Oxygent (DO), salinitas, suhu, $\mathrm{pH}$, kecerahan, nitrit, Biological Oxygent Demand (BOD) dan amonia menunjukkan bahwa lokasi

Tabel 5. Tingkat kesesuaian untuk tiap titik pengamatan

Table 5. Level of suitability for each observation point

\begin{tabular}{|c|c|c|c|c|}
\hline \multirow{2}{*}{$\begin{array}{l}\text { Titik } \\
\text { pengamatan }\end{array}$} & \multirow[b]{2}{*}{ Sangat sesuai (S1) } & \multicolumn{3}{|c|}{ Tingkat kelayakan/kesesuaian } \\
\hline & & Cukup sesuai (S2) & Sesuai bersyarat (S3) & Tidak sesuai $(\mathrm{N})$ \\
\hline Titik P1 & & & $\sqrt{ }$ & \\
\hline Titik P2 & & & & $\sqrt{ }$ \\
\hline Titik P3 & & & & $\sqrt{ }$ \\
\hline Titik P4 & $\sqrt{ }$ & & & \\
\hline Titik P5 & & $\sqrt{ }$ & & \\
\hline Titik P6 & & $\sqrt{ }$ & & \\
\hline Titik P7 & & $\sqrt{ }$ & & \\
\hline Titik P8 & & $\sqrt{ }$ & & \\
\hline Titik P9 & & $\sqrt{ }$ & & \\
\hline Titik P10 & & $\sqrt{ }$ & & \\
\hline Titik P11 & & $\sqrt{ }$ & & \\
\hline Titik P12 & $\sqrt{ }$ & & & \\
\hline
\end{tabular}

Hidrodinamika dan Kualitas Perairan untuk Kesesuaian Pembangunan Keramba Jaring Apung (KJA) Offshore di Perairan Keneukai, Nangroe Aceh Darussalam - Koko Ondara, Guntur Adhi Rahmawan, Ulung Jantama Wisha dan Nia 
penelitian di stasiun P4 hingga P12 layak dan sesuai untuk dijadikan sebagai tempat budidaya KJA. Akan tetapi, hal tersebut tidak berlaku untuk parameter nitrat. Terlihat bahwa hasil analisis menunjukkan bahwa nilai nitrat tidak memenuhi syarat untuk dijadikan daerah budidaya perikanan. Berdasarkan hasil analisis dan verifikasi lapangan dengan pertimbangan aspek fisik dan keterjangkauan lokasi, maka Perairan Keneukai dapat direkomendasikan untuk pengembangan budidaya keramba jaring apung.

\section{UCAPAN TERIMA KASIH}

Terima kasih kami ucapkan kepada Nia Naelul Hasenah Ridwan, peneliti dan teknisi serta staf LRSDKP, dinas-dinas terkait dan akademisi Universitas Syah Kuala yang telah membantu terlaksananya kegiatan penelitian ini. Terima kasih juga kami ucapkan kepada Baristand Banda Aceh yang telah membantu melakukan analisis sampel perairan dalam penelitian ini.

Artikel ini telah dipresentasikan di acara Seminar Nasional Kelautan Pada Gelar Riset dan Inovasi Teknologi Kelautan dan Perikanan, 24 - 27 Oktober 2017 di Jakarta.

\section{DAFTAR PUSTAKA}

Ali, A. (2013). Kajian kualitas air dan status mutu air sungai metro di kecamatan sukun kota malang. Jurnal Bumi Lestari, 13(2), (265-274).

Andersson, G., Berggren, H., Cronberg, G., \& Gelin, C. (1978). Effects of planktivorous and benthivorous fish on organisms and water chemistry in eutrophic lakes. Hydrobiologia, 59(1), 9-15.

Basmi, J. (2000). Planktonologi: Plankton sebagai bioindikator kualitas perairan. Makalah, Fakultas Perikanan Instistut Pertanian Bogor, Bogor. Hal 59.

Beveridge, M.C.M. (2004). Cage Aquaculture, $3^{\text {rd }}$ ed. Blackwell Publishing, London. 368p.

Davis, M. L., \& Cornwell, D. A. (1998). Introduction to environmental engineering. McGraw-Hill Education. $822 p$.

Effendi, H. (2003). Telaah kualitas air, bagi pengelolaan sumber daya dan lingkungan perairan. Kanisius, Yogyakarta. p258.

Husnayaen. (2008). Metode cell based modelling untuk penentuan kawasan potensial wisata pesisir dan bahari di pulau weh, nanggroe aceh darussalam. Skripsi. Program Studi Ilmu dan Teknologi Kelautan. Fakultas Perikanan dan Ilmu Kelautan. Institut Pertanian Bogor. Bogor.

Ilhamsyah, Y., Fadli, N., Setiawan, I., \& Haridhi, H. A. (2014). Coral reef bleaching in Weh Island, Indonesia, a natural climate variability or global climate change impact. AACL Bioflux, 7(6), 508-515.

Jeffries, M., \& Mills, D. (1994). Freshwater ecology. principles and applications. John Wiley \& Sons, Chichester, $285 \mathrm{pp}$.

Khasanah, U., \& Heliani, L. S. (2014). Perhitungan nilai chart datum stasiun pasang surut jepara berdasarkan periode pergerakan bulan, bumi, dan matahari menggunakan data pasut tahun 1994 sd 2013. Jurnal Geospasial Indonesia, ISSN, 2222-2863.

KLH. (2004). Keputusan Menteri Negara Lingkungan Hidup Nomor 51 Tahun 2004 tentang baku mutu air laut. Jakarta. 10 hal.

Mahadevan, A., \& Archer, D. (2000). Modeling the impact of fronts and mesoscale circulation on the nutrient supply and biogeochemistry of the upper ocean. Journal of Geophysical Research: Oceans, 105(C1), 1209-1225.

Mayunar, R. Purba \& P.T. Imanto. (1995). Pemilihan lokasi untuk usaha budidaya ikan laut. Prosiding Temu Usaha Pemanfaatan keramba Jaring Apung bagi Budidaya Laut. Puslitbang Perikanan, Badan Litbang Pertanian. p179-189.

Murtiono, L. H., Yunianto, D., \& Nuraini, W.(2016). Analisis kesesuaian lahan budidaya kerapu sistem keramba jaring apung dengan aplikasi sistem informasi geografis di perairan Teluk Ambon Dalam. Jurnal Teknologi Budidaya Laut. Vol 6:1-15.

Ondara, K., \& Wisha, U. J. (2016). Simulasi Numerik gelombang (spectral waves) dan bencana rob menggunakan flexible mesh dan data elevation model di perairan Kecamatan Sayung, demak. Jurnal Kelautan: Indonesian Journal of Marine Science and Technology, 9(2), 164-174.

Rudi, E., Iskandar, T., Fadli, N., \& Hidayati, H. (2012) Impact of mass coral bleaching on reef fish community and fishermen catches at Sabang, Aceh Province, Indonesia. Aquaculture, Aquarium, Conservation \& Legislation-International Journal of the Bioflux Society (AACL Bioflux), 5(5).

Shamsi, S., Eisenbarth, A., Saptarshi, S., Beveridge, I., Gasser, R. B., \& Lopata, A. L. (2011). Occurrence and abundance of anisakid nematode larvae in five species of fish from southern Australian waters. Parasitology research, 108(4), 927-934.

Simanjuntak, B. L., Handoyo, G., \& Sugianto, D. N. (2012). Analisis bathimetri dan komponen pasang surut untuk penentuan kedalaman tambahan kolam dermaga di Perairan Tanjung Gundul Bengkayang-Kalimantan Barat. Journal of Oceanography, 1(1), 1-8.

Supriyono., Pranowo, W. S., Rawi, S., \& Herunadi, B. (2015). Analisa dan Perhitungan Prediksi Pasang Surut Menggunakan Metode Admiralty dan Metode Least Square (Studi Kasus Tarakan dan Balikpapan). J. Chart Datum 1(1):8-18.

Sutomo, S., (1989). Pengaruh amonia terhadap ikan dalam budidaya sistem tertutup. Oseano XIV (1), 19-26.

Wedemeyer, G. (1996). Physiology of fish in intensive culture systems. Springer Science \& Business Media. 232p

Wirasatriya. A., \& Supriyanto. S. (2004). Perkembangan awal larva Tiram Mutiara (Pintada maxima) pada

JURNAL KELAUTAN NASIONAL, Vol. 12, No 2, Agustus 2017, Hal. 45-57 
tingkat salinitas yang berbeda. Indonesia Journal of Marine Science, UNDIP, Semarang. Vol 9. No. 1, hal $14-19$.

Wisha, U. J., Husrin, S., \& Prasetyo, G. S. (2016). Hydrodynamics of Bontang Seawaters: Its effects on the distribution of water quality parameters. Indonesian Journal of Marine Sciences/Ilmu Kelautan, 21(3).

Zamani, N. P., \& Arifin, T. (2016). Hubungan parameter lingkungan terhadap gangguan kesehatan karang di pulau tunda--banten. Jurnal Kelautan Nasional, 11(2). 